Reprod. Nutr. Dévelop., 1985, 25 (1 A), 93-100.

\title{
Dietary fiber and cholesterol and bile acid metabolism in axenic (germfree) and holoxenic (conventional) rats. - III. Effect of non-sterilized pectin
}

\author{
E. SACQUET, C. LEPRINCE, M. RIOTTOT, P. RAIBAUD $(*)$
}

Laboratoire des Animaux sans Germes du C.N.R.S

(*) Laboratoire d'Ecologie microbienne

I.N.R.A., 78350, Jouy-en-Josas, France.

Summary. Axenic (germfree) and holoxenic (conventional) rats were given a pectincontaining diet $(5 \%)$ or a pectin-free diet. The diet was not sterilized and the axenic state was maintained by the addition of antibiotics.

Pectin modified little or not at all the quantity of bile acids in the small intestine, fecal bile acid excretion and fecal elimination of the sum of cholesterol and bile acids. It similarly decreased the concentration of liver cholesterol and the amount of bile acids in the cecum and large intestine of both germfree and conventional rats. Pectin decreased the absorption coefficient of dietary cholesterol and its plasma concentration and increased fecal cholesterol elimination in conventional rats but not in germfree animals. The data imply that some of the actions of pectin depend on the presence of the intestinal flora but the exact nature of this relationship is unclear.

\section{Introduction.}

It is generally agreed that pectin intake changes the metabolism of cholesterol and bile salts. The way this substance acts is not known and it has been the object of various hypotheses (Vahouny, 1982). The involvement of digestive tract microbial flora in the effects of pectin has not been elucidated, and the notion was rejected by Vahouny (1982) who did not observe any changes in the effect of pectin on cholesterol level in the plasma and liver when conventional rats received $1 \%$ of succinylsulfathiazole.

In a previous study (Sacquet, Leprince and Riottot, 1982b) to elucidate the role of microbial flora, we compared the effects of pectin in germfree (GF) and conventional (CV) rats. The pectin-containing diet and the pectin-free one were sterilized by gamma irradiation at $40 \mathrm{KGray}$. This experiment was not conclusive because most of the effects that pectin usually produces were not present, particularly in CV rats. This led us to hypothesize that gamma irradiation destroys the hypocholesterolemiant activity of pectin. 
The present experiment was similar to the previous one, except that the diet was not sterilized. The axenic state of the GF rats was maintained by adding antibiotics into the diet.

\section{Material and methods.}

The antibiotic mixture contained (in $\mathrm{g} / \mathrm{kg}$ of diet) : fungizone 1, ampicillin 2.5 , bacitracin 2.4, streptomycin sulfate 2.5 . This mixture was added into the diet of GF rats at the time it was prepared. The diet was then put into vacuum-sealed bags and introduced into the isolator under peracetic spray. The rest of the protocol was similar to that used in the predecing experiments (Sacquet, Leprince and Riottot, 1982a, b). Briefly, the pectin belonged to the same lot as that of the previous study i.e. highly methylated $(73.6 \%)$ apple pectin manufactured by Unipectine (France). It was added to a basic diet (diet $O$ ) at the rate of $5 \%$ of the weight (diet P). The basic diet contained no dietary fiber and $0.1 \%$ cholesterol and included (in g) : saccharose 61, casein 22.1, cornoil 9.7, mineral salts 4.8, vitamin mixture 1. When it was given to the rats, $20 \%$ of its weight in water was added.

We used male Fischer rats of strain 344. They received either diet $O$ or $P$ and were divided into experimental groups GFO, GFP, CVO, CVP. Two experiments were carried out, one to establish the isotopic cholesterol equilibrium and the other to measure the absorption coefficient of cholesterol.

The method of isotopic cholesterol equilibrium was employed for technical reasons. When isotopic equilibrium is reached, hepatic and plasma cholesterol and all the chemical species of bile acids have the same specific activity, making it easy to determine them. After hot ethanol extraction in a Kumagawa apparatus, the neutral and acid sterols were separated by the method of Grundy, Ahrens and Miettinen (1965). Hepatic cholesterol was determined by the method of Liebermann. Fecal cholesterol was determined using thin-layer chromatography to separate the cholesterol ; it was then assayed by gas-liquid chromatography on a 2-m long pyrex column containing $3 \%$ OV17 and $3 \%$ QF1 absorbed in equal parts on chromosorb WHMD S $80 / 100$ mesh at $225^{\circ} \mathrm{C}$.

The cholesterol absorption coefficient was measured using the method of Crouse and Grundy (1978). Another group of rats was put in experimental conditions similar to those of the isotopic equilibrium group and, at the end of a 3 -week period, was given a constant daily dose of $\left(1,2-{ }^{3} \mathrm{H}\right)$-cholesterol and of $\left(4-{ }^{14} \mathrm{C}\right)-\beta$-sitosterol in the diet for one week. The feces were collected everyday, saponified and extracted with petroleum ether. The absorption coefficient was calculated using the formula :

$$
A C=100\left(1-\frac{{ }^{3} \mathrm{H} /{ }^{14} \mathrm{C} \text { excreted }}{{ }^{3} \mathrm{H} /{ }^{14} \mathrm{C} \text { ingested }}\right)
$$

The results of each studied character were expressed by the mean value and the SEM (SE of the mean). The four experimental groups were compared by twofactor analysis of variance (Snedecor and Cochran, 1957), and the interactions of the two factors (microbial flora and pectin) were determined. 


\section{Results.}

The antibiotic mixture completely protected the GFO rats from microbes in the diet. Examination of the feces of the GFP rats revealed they were contamined with a mold; but the number of living cells did not exceed $10^{4}$ per $\mathrm{g}$ of wet weight.

Compared to CV rats, the dietary intake of GF animals was slightly less, their cecum was much more voluminous and had a higher water content and their body weight was slightly lower at the end of the experiment (table 1). This difference cannot be entirely explained by differences in initial weight and might be the result of the presence of antibiotics in the diets (fig. 1). Pectin itself had only minor effects on the weight of the cecum and its water content and on body weight ; the GFO rats remained comparable to the GFP rats and the CVO ones to CVP animals.

\section{TABLE 1}

Age, body weight, feed intake, cecal weight and water content in axenic (GF) and holoxenic (CV) rats fed the pectin-containing (P) or the pectin-free (O) diet.

$$
1 \text { - Mean } \pm S E M \text { of } 4 \text { rats. }
$$

\begin{tabular}{|c|c|c|c|c|}
\hline Groups & GFO & GFP & CVO & CVP \\
\hline $\begin{array}{l}\text { Age at the end of the experiment (days) } \\
\text { Body weight }(g) \ldots \ldots \ldots \ldots \ldots \ldots \ldots \\
\text { Feed intake }(g / \text { day) } \ldots \ldots \ldots \ldots \ldots \ldots \\
\text { Cecal weight } / 100 \mathrm{~g} \text { body weight } \ldots \ldots \ldots \\
\text { Cecal water content (p. } 100) \ldots \ldots \ldots \ldots\end{array}$ & $\begin{array}{l}124 \\
273 \pm 3 \\
11.9 \pm 0.1 \\
5.6 \pm 0.31 \\
82.4 \pm 0.1\end{array}$ & $\begin{aligned} 124 & \\
263 & \pm 5 \\
12.3 & \pm 0.3 \\
6.8 & \pm 0.41 \\
84.9 & \pm 0.3\end{aligned}$ & $\begin{aligned} 123 & \\
303 & \pm 11 \\
13.7 & \pm 0.4 \\
1.1 & \pm 0.07 \\
81.1 & \pm 0.2\end{aligned}$ & $\begin{array}{ll}127 & \\
294 & \pm 3 \\
13.3 & \pm 0.2 \\
1.1 & \pm 0.09 \\
79.9 & \pm 0.7\end{array}$ \\
\hline
\end{tabular}

\section{2 - Analysis of variance}

\begin{tabular}{|c|c|c|c|}
\hline Factors & Microflora & Pectin & Interaction \\
\hline Cecal weight $\ldots .$. & $x \times x(1)$ & $x$ & $\mathbf{x}$ \\
\hline Cecal water content $\ldots \ldots \ldots \ldots \ldots$ & $\mathbf{x x x}$ & NS & $\mathbf{x x x}$ \\
\hline
\end{tabular}

(1) $x x x: p<0.005 ; x x: p<0.01 ; x: p<0.05 ; N S=$ non-significant.

The effects of pectin on cholesterol and bile acid metabolisms are presented on table 2. The values of $A C$ in all groups stabilized on day 4 . These day-4 values were considered as the best estimates of the real cholesterol absorption coefficient. Some effects of pectin on cholesterol and bile acid metabolisms were similar in GF and CV rats. Pectin decreased cholesterol concentration in the liver (line 3) and the amount of bile acids in the cecum and large intestine (line 8) in GFP and CVP rats. It did not modify the amount of bile acids in the small intestine (line 7) nor change their fecal excretion significantly (line 5). 


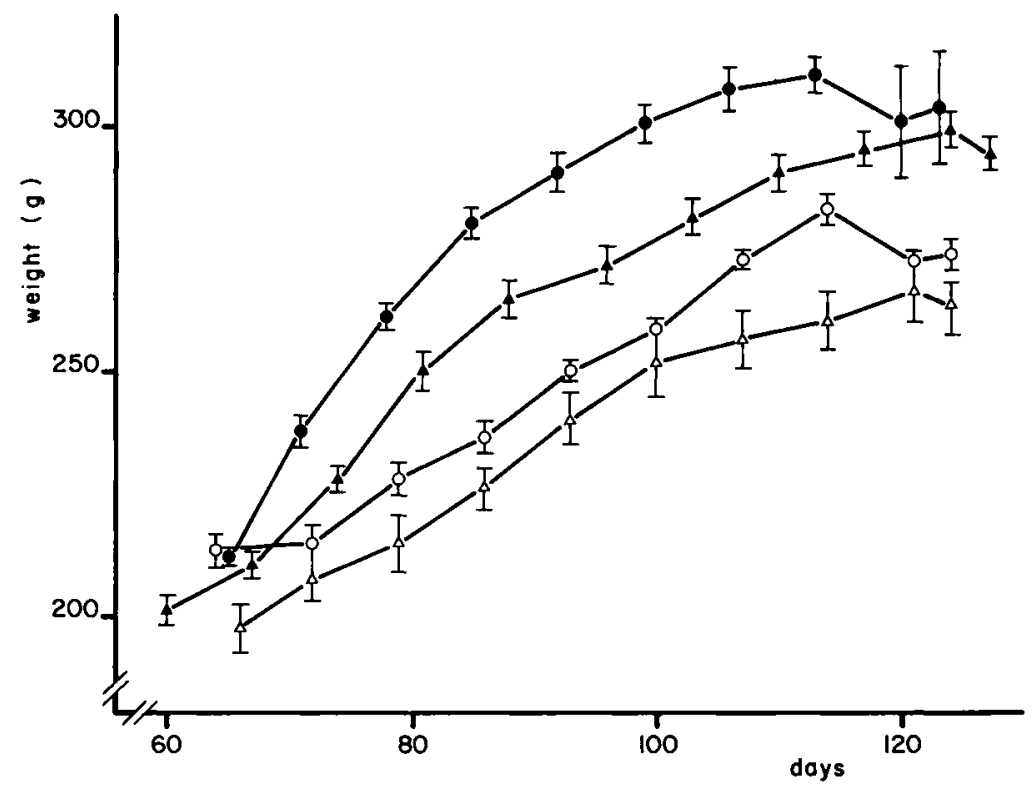

FIG. 1. - Growth of axenic (GF) and holoxenic (CV) rats receiving the pectin-containing (P) or pectin-free diet $\langle 0\rangle$. Ascissa : days. Ordinate: weights $(\mathrm{g})$. Mean $\pm \mathrm{SEM}$ of : GFO, O ; GFP, $\triangle$; CVO, $\bullet$; CVP, $\Delta$.

On the contrary, pectin decreased the absorption coefficient of cholesterol (line 1) as well as its concentration in the plasma (line 2) and increased its fecal elimination (line 4) in CVP but not in GFP animals.

The values of the absorption coefficient of dietary cholesterol permitted evaluation of the non-absorbed cholesterol in the feces. This was expressed in $\mathrm{mg} /$ day $/ 100 \mathrm{~g}$ of body weight and varied from 1.54 in CVO to 1.80 in CVP, showing an increase of 0.26 , while total fecal cholesterol augmented by 1.73 . The increase in fecal cholesterol in CVP was thus mostly due to plasma cholesterol (excretion) and/or to cholesterol from the intestinal epithelium (external secretion), according to the concept of Chevallier and Lutton (1966). Fecal elimination of the sum of cholesterol and bile acids showed a slight, nonsignificant increase in both groups of rats.

\section{Discussion.}

In this experiment, we observed most of the usual effects of pectin seen in conventional rats (Vahouny, 1982) and absent in the previous experiment (Sacquet, Leprince and Riottot, 1982b). Therefore, we assume that gamma irradiation at $40 \mathrm{KGray}$ was probably responsible for nullifying the properties of the pectin. The viscosity of a sample of this pectin, irradiated in the same way as in the previous experiment, decreased from 43 to 15 centipoises and its gelling 
TABLE 2

Absorption coefficient of dietary cholesterol, cholesterol levels and fecal elimination, fecal bile acid excretion and intestinal pools in axenic (GF) and holoxenic (CV) rats fed the pectin-containing (P) or pectin-free $(\mathrm{O})$ diet.

1 - Mean \pm SEM of 4 rats.

\begin{tabular}{llllll}
\hline Groups & GFO & GFP & CVO & CVP \\
\hline
\end{tabular}

1. Absorption coefficient of cholesterol (p. 100$) \ldots \ldots \ldots \ldots \ldots \ldots \ldots \ldots$

2. Cholesterol concentration in plasma (mg/100 ml) ....................

3. Cholesterol concentration in liver (mg/100 g fresh liver weight) $\ldots \ldots \ldots$.

4. Fecal elimination of cholesterol:$\mathrm{mg} / 100 \mathrm{~g}$ body weight/day ............

5. Fecal bile acid excretion ( $\mu$ moles $/ 100 \mathrm{~g}$

$$
62.0 \pm 0.4
$$

$102 \pm 2.3$

$63.3 \pm 1.5$

$64.8 \pm 1.3$

$58.9 \pm 1.4$

$$
342 \pm 13.7
$$

$97 \pm 3.3$

$130 \pm 4.2$

$80 \pm 3.4$

$2.47 \pm 0.10$

$299 \pm 5.5$

$365 \pm 28.2$

$270 \pm 7.7$

body weight/day) ................

bile acids ( $\mu$ moles $/ 100 \mathrm{~g}$ body weight/

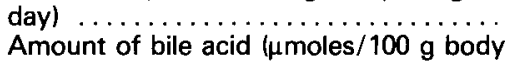

$$
6.4 \pm 0.26
$$

$2.35 \pm 0.20$

$2.86 \pm 0.41$

$6.2 \pm 0.50$

$7.4 \pm 1.07$

$4.59 \pm 0.14$

$11.5 \pm 0.7$

$14.0 \pm 0.7$

$12.0 \pm 1.4$

$11.8 \pm 0.35$

$17.9 \pm 0.8$

$20.2 \pm 1.2$

$19.4 \pm 2.2$

$11.0 \pm 0.9$ weight) :

in the small intestine

$43.6 \pm 2.1$

$47.4 \pm 3.5$

$46.5 \pm 2.0$

$20.1 \pm 1.1$

$20.3 \pm 1.7$

\begin{tabular}{|c|c|c|c|}
\hline Factors & Microflora & Pectin & Interaction \\
\hline 1. Absorption coefficient of cholesterol & NS (1) & NS & $x$ \\
\hline 2. Cholesterol concentration in plasma & NS & $x \times x$ & $x x x$ \\
\hline 3. Cholesterol concentration in liver .... & NS & $\mathrm{x}$ & NS \\
\hline 4. Fecal elimination of cholesterol .... & $\mathbf{x x x}$ & $x x$ & $\mathbf{x x x}$ \\
\hline 5. Fecal excretion of bile acids .. & NS & NS & NS \\
\hline 6. Total fecal elimination of cholesterol and bile acids & NS & NS & NS \\
\hline 7. Amount of bile acid in the small intestine ........ & $\mathbf{x x x}$ & NS & NS \\
\hline in the cecum and large intestine & $\mathbf{x x x}$ & $x x x$ & $\mathbf{x}$ \\
\hline
\end{tabular}

$30.9 \pm 1.8 \quad 21.6 \pm 0.6 \quad 16.7 \pm 1.4$

\section{2 - Analysis of variance.}

(1) Same meaning as in table 1.

power disappeared (Petit, 1982), confirming that the hypocholesterolemiant activity of pectin is linked to its gelling power. As irradiation alters pectin, the addition of antibiotics to the diet seemed to be the only way of maintaining the axenic state in GFP rats, but the GF and CV rats differed not only as to the presence or absence of flora but also as to the presence or absence of antibiotics, the putative secondary effects of which could not be known.

The above reservation being stated, pectin produced effects in $\mathrm{CV}$ rats that we did not find in GF animals ; the microbial flora of the digestive tract would be implicated in these effects. This is contrary to the conclusions of Vahouny (1982) who observed no changes in the effects of pectin in CV rats treated with 
succinylsulfathiazole. These divergencies are easily explainable. It is hardly credible that the treatment with this sulfamide would make the $\mathrm{CV}$ rats similar to the GF animals ; much more complicated techniques are required to completely suppress the intestinal microflora (Van der Waaij, 1968).

The differences between $\mathrm{GF}$ and $\mathrm{CV}$ rats are not limited to intestinal flora digestion of pectin or to the resulting transformations of cholesterol and bile acid molecules. GF and $\mathrm{CV}$ rats differ as to the morphology of the intestinal mucosa (Meslin, Sacquet and Guenet, 1973), the abundance of mucus-producing glands (Heneghan, 1978), rate of intestinal epithelium renewal (Meslin, Sacquet and Riottot, 1981), rate of intestinal transit (Sacquet, Garnier and Raibaud, 1970), amount of bile acids present in the intestine (particularly in the small intestine ; Riottot et al., 1980) and their intestinal absorption and secretion in the bile duct (Riottot, Sacquet and Leprince, 1980), dietary lipid digestibility (Demarne et al., 1970) and insulinemia (Sewell et al., 1976). However, these physiological characteristics would be involved in the action of pectin on the metabolism of cholesterol, bile acids and other lipids in CV rats (Vahouny, 1982). The effects of pectin, especially the lowering of cholesterolemia, cannot be explained only by a decrease in cholesterol and/or bile acid absorption. Commenting on work on the distribution of cholesterol in the different classes of lipoproteins, Story and Kelly (1982) wrote : " Little evidence has come forth to suggest any mechanism for the observed changes in lipoprotein cholesterol levels. "

Thus, it is not easy to explain why pectin is ineffective in GF rats. It is conceivable that a high bile acid concentration would protect the cholesterol from being coated with pectin as it would protect saturated fatty acids from calcium precipitation (Demarne et al., 1974). The high amount of bile salts present in GF rats would allow the cholesterol to continue to be normally absorbed, esterified and incorporated into the chylomicrons and lipoproteins, and thus the overall metabolism would not be modified. It is also possible that the slowing-down of epithelium renewal in GF rats is accompanied by changes in enterocyte metabolism, for example, in lipoprotein biosynthesis or in the incorporation of cholesterol into the enterocytes, and that the ineffectiveness of pectin is due to these modifications in the enterocyte.

The absence of certain effects of pectin on GF rats therefore creates an interesting situation. Various factors of the GF state can be manipulated. For example, the addition of $10 \%$ lactose to the diet of GF rats results in a similar renewal of the epithelium in GF and CV rats (Meslin, Sacquet and Raibaud, 1981) but does not modify the bile acid content of the small intestine (Sacquet, Leprince and Riottot, 1979). Adding $5 \%$ of sodium taurocholate to the diet of $\mathrm{CV}$ rats increases the amount of bile acids in the small intestine of those rats and reproduces the characteristic dietary lipid digestion observed in GF rats (Demarne et al., 1974). It is thus possible to carry out methodical experimentation in order to distinguish which factor of the GF state nullifies the action of pectin. 
Résumé. Fibre alimentaire et métabolisme du cholestérol et des acides biliaires chez les rats axéniques et holoxéniques. III. Effet de la pectine non-stérilisée.

Des rats axéniques et holoxéniques ont été nourris à l'aide d'un aliment contenant ou non $5 \%$ de pectine. L'aliment n'a pas été stérilisé et l'état axénique a été maintenu en ajoutant à l'aliment un mélange d'antibiotiques.

La pectine n'a pas, ou a peu, modifié la quantité d'acides biliaires dans l'intestin grêle, l'élimination fécale de la somme du cholestérol et des acides biliaires. Elle a diminué de manière semblable chez les rats axéniques et chez les rats holoxéniques la concentration du foie en cholestérol et la quantité d'acides biliaires dans le cæecum-gros intestin. Elle a diminué le coefficient d'absorption du cholestérol alimentaire, sa concentration dans le plasma et augmenté son élimination fécale chez les rats holoxéniques, mais pas chez les rats axéniques. La flore microbienne du tractus digestif serait impliquée dans ces derniers effets, mais la nature exacte de cette relation n'est pas claire.

\section{References}

CHEVALLIER F., LUTTON C., 1966. Vitesses de renouvellement du cholestérol contenu dans son espace de transfert : I. Méthodes et résultats obtenus dans le cas d'un régime semi-synthétique témoin. Bull. Soc. Chim. biol., 48, 507-524.

CROUSE J. B., GRUNDY S. M., 1978. Evaluation of a continuous isotope feeding method for measurement of cholesterol absorption in man. J. Lipid Res., 19, 967-971.

DEMARNE Y., SACQUET E., FLANZY J., GARNIER H., FRANÇOIS A. C., 1970. Utilisation digestive apparente des acides gras chez le rat axénique et holoxénique. Ann. Biol. anim. Biochim. Biophys., 10, 369-384.

DEMARNE $Y_{.}$, SACQUET E., VAN HEIJENOORT Y., MATHIS C., 1974. Influence d'une supplémentation de la ration en sels biliaires conjugués sur l'équipement en acides biliaires de l'intestin grêle du rat. Modification de l'absorption apparente des acides gras. Ann. Biol. anim. Bioch. Biophys., 14, 239-250.

GRUNDY S. M., AHRENS E. H., MIETTINEN T. A., 1965. Quantitative isolation and gas-liquid chromatographic analysis of total fecal bile acids. J. Lipid Res., 6, 397-410.

HENEGHAN J. B., 1978. Enterocyte kinetics, mucosal surface area and goblet cells in gnotobiotics. 6 th int. Symp. Gnotobiotics. June 1978, Ulm/Donau, Fed. Rep. Germany.

MESLIN J. C., SACQUET E., GUÉNET J. L., 1973. Action de la flore bactérienne sur la morphologie et la surface de la muqueuse de l'intestin grêle du rat. Ann. Biol. anim. Biochim. Biophys., 13, $203-214$.

MESLIN J. C., SACQUET E., RIOTTOT M., 1981. Effect of various modifications in the diet on ileal epithelium renewal in germ-free and conventional rats. Reprod. Nutr. Dévelop., 21, 651-659.

PETIT R., 1982. Unipectine S.A. (France) Communication personnelle.

RIOTTOT M., SACQUET E., VILA J. P., LEPRINCE C., 1980. Relationship between smal intestine transit and bile acid metabolism in axenic and holoxenic rats fed different diets. Reprod. Nutr. Dévelop., 20, 163-171.

RIOTTOT M., SACOUET E., LEPRINCE C., 1980. Variations of bile salt pool size and secretion rate in rats according to the modes of sterilization and preparation of a semi-synthetic diet. Reprod. Nutr. Dévelop., 20, 1481-1488.

SACQUET E., GARNIER H., RAIBAUD P., 1970. Etude de la vitesse du transit gastro-intestinal des spores d'une souche thermophile stricte de Bacillus subtilis chez le rat holoxénique, le rat axénique, le rat axénique caecectomisé. C. R. Soc. Biol., 164, 352-355.

SACQUET E., LEPRINCE C., RIOTTOT M., 1979. Effect of different modifications of a semisynthetic diet on bile acid metabolism in axenic and holoxenic rats. Ann. Biol. anim. Bioch. Biophys., 19, 1677-1688. 
SACQUET E., LEPRINCE C., RIOTTOT M., 1982a. Dietary fiber and cholesterol and bile acid metabolisms in axenic (germfree) and holoxenic (conventional) rats. I. Effect of wheat bran. Reprod. Nutr. Dévelop., 22, 291-305.

SACQUET E., LEPRINCE C., RIOTTOT M., 1982b. Dietary fiber and cholesterol and bile acid metabolisms in axenic (germfree) and holoxenic (conventional) rats. II. Effect of pectin. Reprod. Nutr. Dévelop., 22, 575-581.

SWEELL D. L., BRUCKNER-KARDOSS E., LORENTZ L. M., WOSTMANN B. S., 1976. Glucose tolerance, insulin and catecholamine levels in germfree rats. Proc. Soc. exp. Biol. Med., 152, 16-19.

SNEdeCOR G. W., COCHRAN W. G., 1957. Méthodes statistiques, 6e édit. A.C.T.A. Paris, 319-324.

STORY J. A., KELLY M. J., 1982. Dietary fiber and lipoproteins, 229-238. In VAHOUNY G. V., KRITCHEVSKY D. Dietary fiber in health and disease. Plenum Press, New York and London.

VAHOUNY G. V., 1982. Dietary fibers and intestinal absorption of lipids, 203-227. In VAHOUNY G.V., KRITCHEVSKY D., Dietary fiber in health and disease. Plenum Press, New York and London.

WAAIJ D. van der, 1968 . Production of bacteria-free mice by antibiotic decontamination, 30-37. In MIYAKAWA M. and LUCKEY R. D. Advances in germfree research and gnotobiology. CRC Press, Cleveland. 